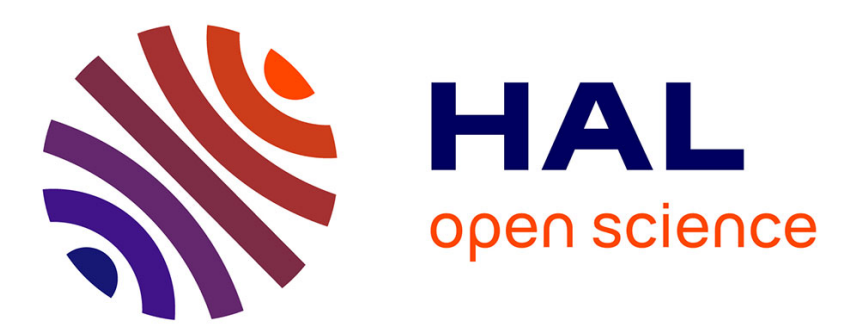

\title{
Influence of temperature on sorption process in hemp concrete
}

Yacine Aït Oumeziane, Sophie Moissette, Marjorie Bart, Christophe Lanos

\section{To cite this version:}

Yacine Aït Oumeziane, Sophie Moissette, Marjorie Bart, Christophe Lanos. Influence of temperature on sorption process in hemp concrete. Construction and Building Materials, 2016, 106, pp.600-607. 10.1016/j.conbuildmat.2015.12.117 . hal-01259417

\section{HAL Id: hal-01259417 https://hal-univ-rennes1.archives-ouvertes.fr/hal-01259417}

Submitted on 27 Jan 2016

HAL is a multi-disciplinary open access archive for the deposit and dissemination of scientific research documents, whether they are published or not. The documents may come from teaching and research institutions in France or abroad, or from public or private research centers.
L'archive ouverte pluridisciplinaire HAL, est destinée au dépôt et à la diffusion de documents scientifiques de niveau recherche, publiés ou non, émanant des établissements d'enseignement et de recherche français ou étrangers, des laboratoires publics ou privés. 


\section{INFLUENCE OF TEMPERATURE ON SORPTION PROCESS IN HEMP CONCRETE}

Yacine Aït Oumeziane $(\bowtie)$, Institut FEMTO-ST, Département ENERGIE,

Parc technologique 2, avenue Jean Moulin 90000 Belfort

e-mail: yacine.ait_oumeziane@univ-fcomte.fr

Tel: +33787612491

Sophie Moissette, Université Européenne de Bretagne, Laboratoire de Génie Civil et Génie Mécanique, Equipe Matériaux Thermo Rhéologie,

IUT Rennes, 3 rue du Clos Courtel, BP 9042235704 Rennes (France)

e-mail: sophie.moissette@univ-rennes1.fr

Marjorie Bart, Université Européenne de Bretagne, Laboratoire de Génie Civil et Génie Mécanique, Equipe Matériaux Thermo Rhéologie,

IUT Rennes, 3 rue du Clos Courtel, BP 9042235704 Rennes (France)

e-mail: marjorie.bart@univ-rennes1.fr

Christophe Lanos, Université Européenne de Bretagne, Laboratoire de Génie Civil et Génie Mécanique, Equipe Matériaux Thermo Rhéologie,

IUT Rennes, 3 rue du Clos Courtel, BP 9042235704 Rennes (France)

e-mail: Christophe.Lanos@univ-rennes1.fr 


\section{Abstract}

Hemp concrete is a bio-based material which is currently undergoing a growing development. Its hygrothermal behaviour highly depends on the evolution of the moisture content which has a significant influence on heat and moisture transfer. Hysteresis phenomenon and temperature effects on sorption process make difficult the prediction of the moisture content evolution. Hysteresis phenomenon determines the equilibrium moisture content during successive adsorption / desorption cycles. Temperature influences also the equilibrium moisture content: the warmer the temperature, the lower will be the equilibrium moisture content at the same relative humidity. These two phenomena are most often neglected for modelling the moisture content evolution in heat and moisture transfer models. This can cause significant discrepancies to predict the hygrothermal response of a material subjected to climatic variations.

This paper intents to contribute to the better knowledge of such sorption processes by providing new measurements and by analysing and comparing different theoretical approaches. Some adsorption and desorption main and intermediate scanning curves are measured at two different temperatures. Models taking into account these phenomena are presented. The comparison between experimental and numerical results shows that the theoretical approaches investigated are promising.

\section{Keywords}

Bio-based material; Hemp concrete; Hysteresis; Sorption process; Temperature

\section{Introduction}

In a context of sustainable development, one of the concerns in the building construction sector is the choice of environmentally friendly and healthy materials. In the French climatic conditions, bio-based materials appear as a good solution to address energetic and environmental issues [1]. Different compositions and methods of manufacturing give to hemp 
concrete a variety of use: wall, floor and roof. For wall, hemp concrete can be precast, moulded in place or sprayed. Because of low mechanical properties [2], it is mainly used as a filling material supported on a timber frame.

Previous studies on hemp concrete showed its interesting hygrothermal properties as building materials: a low bulk density from 300 to $500 \mathrm{~kg} \cdot \mathrm{m}^{-3}$, a low thermal conductivity of about 0.1 $\mathrm{W} \cdot \mathrm{m}^{-1} \cdot \mathrm{K}^{-1}$ and a high vapour permeability of $10^{-11}-10^{-10} \mathrm{~kg} \cdot \mathrm{m}^{-1} \cdot \mathrm{s}^{-1} \cdot \mathrm{Pa}^{-1}[3-7]$. Its porous, hygroscopic and permeable structure gives high moisture transfer and storage capacities. In [8-9], the high moisture buffer value of hemp concrete confirmed its excellent moisture buffer performance. In practice, the monitoring of an individual French dwelling-house made of 30 cm thick sprayed hemp concrete associated with a timber frame structure [10] and of an experimental hemp-lime building house in England [11] showed its ability to dampen variations of temperature and relative humidity. Previous works showed the significant influence of moisture content on heat and moisture transfer and storage [7, 12-15]. The derivation of the hygrothermal response to climatic variations of a bio-based material like hemp concrete needs thus a thorough knowledge of the moisture content evolution.

As observed for many hygroscopic materials, a significant hysteresis occurs in the hemp concrete sorption process $[5,13]$. For these materials, the equilibrium moisture content depends not only on relative humidity but also on moisture history. For hemp concrete, the hysteretic phenomenon was experimentally and numerically studied at the reference temperature of $23^{\circ} \mathrm{C}$ in [13]. In this work, the Huang hysteresis model [16] showed its suitability to numerically predict the hemp concrete hysteretic behaviour. Numerical results in good agreement with experimental ones showed the relevance to consider the hysteresis phenomenon to simulate the transient hygric response of hemp concrete [13-15]. 
These results were obtained at ambient temperature (about $23^{\circ} \mathrm{C}$ ) but temperature variations can also affect the evolution of moisture content $[17,18]$. The latest experimental research highlights the influence of temperature on moisture content for cement-based materials and ordinary concrete [19-23]. Some experimental investigations were also performed on wood $[24,25]$. These studies were mainly focused on a high range of temperatures over $20^{\circ} \mathrm{C}$ up to $80^{\circ} \mathrm{C}$ for specific applications (durability, drying process...). Others dealt with organic-based products in a temperature range close to the one encountered in operative building applications between $0^{\circ} \mathrm{C}$ and $40^{\circ} \mathrm{C}$ [26-29]. In all studies, the warmer the temperature, the lower the equilibrium moisture content at the same relative humidity was. In this framework, theoretical and numerical approaches are developed to predict the temperature's effect on moisture content. Three main theories try to explain the influence of temperature on sorption isotherms. The modification of the pore structure due to temperature is one explication. Determination of specific surface areas and mercury intrusion porosimetry tests on cement-based material were performed at different temperatures [30-31]. A temperature increase between ambient temperature and $90^{\circ} \mathrm{C}$ or $100^{\circ} \mathrm{C}$ results in a reduction of the specific surface area. The comparison of the pore size distributions shows the presence of pores with larger diameters at $80^{\circ} \mathrm{C}$ than at $30^{\circ} \mathrm{C}$. A modification of the microstructure by an enlargement of pores can thus be attributed to a rise of temperature. This can explain the modification of the sorption isotherms shapes until a temperature of $60^{\circ} \mathrm{C}$ [32]. Nevertheless, this approach is to be found insufficient to explain the decrease of moisture content at saturation observed in a large range of temperature (between $20^{\circ} \mathrm{C}$ and $80^{\circ} \mathrm{C}$ ) for cementbased materials [21-23]. To overcome the limitations of the microstructure alteration with the increase of temperature, the modification of the water thermophysical properties with temperature was also investigated together with coarsening of the pore structure $[33,34]$ or without [35]. Poyet suggested that the microstructure alteration and the water properties 
evolution had negligible effects and did not fully explain the results obtained for concrete [21]. He proposed a new approach based on the thermodynamic evolution of sorption mechanism [21]. He based his approach on the exothermic process of adsorption [36] and on the principle of Le Chatelier and the rule of Van't Hoff. According to these principles, increasing temperature promotes the reverse process of adsorption, namely desorption. This approach was validated on cement pastes and concretes [21 37].

Research on temperature effects, on hysteresis effects or on the coupling between temperature and hysteresis are rather scarce in literature. Rode et al. [38] provided some measurements for several building materials (cement paste, spruce, aerated concrete). For the three temperatures investigated $\left(10^{\circ} \mathrm{C}, 25^{\circ} \mathrm{C}\right.$ and $\left.40^{\circ} \mathrm{C}\right)$, no significant differences were observed for aerated concrete both in adsorption and desorption for a range of relative humidity between $10 \%$ and $80 \%$. For very high relative humidities over $80 \%$ and very low below $10 \%$, more differences are observed between each sorption isotherms. Furthermore, the results obtained by Rode et al. are in accordance with the hypothesis of Ishida [39] which assumes that an increase of temperature results in a reduction of the hysteresis loop.

This paper aims to provide some experimental measures to identify the influence of both temperature and hysteresis on the moisture content evolution in hemp concrete. The range of relative humidity between $20 \% \mathrm{RH}$ and $85 \% \mathrm{RH}$ chosen in this paper is supposed to be representative of the variations in France for a hemp concrete wall in typical configuration. Hysteresis phenomenon is modelled using the Huang hysteresis model. The theoretical approach (thermodynamic equilibrium move) used for concretes and cement-based materials is applied in the case of hemp concrete. The performance of the thermodynamic model is compared with experimental results collected on hemp concrete at two different temperatures. This approach is extended to model the influence of both hysteresis and temperature and the results are discussed. 


\section{Theory}

\subsection{Sorption isotherm modelling}

Different approaches are to be found in literature to model the sorption isotherms. In this paper, two models are chosen and compared: the GAB model based on the physical sorption mechanism [40-44] and the Van Genuchten (VG) model based on the moisture transport [45]. The GAB equation is described by Eq. (1):

$$
\begin{aligned}
& u_{j}(R H)=\frac{a_{j} b_{j} u_{m} R H}{\left(1-b_{j} R H\right)\left[1+\left(a_{j}-1\right) b_{j} R H\right]}=\frac{u_{s a t} R H\left(1-b_{j}\right)\left[1+\left(a_{j}-1\right) b_{j}\right]}{\left(1-b_{j} R H\right)\left[1+\left(a_{j}-1\right) b_{j} R H\right]} \\
& j=\text { ads or des }
\end{aligned}
$$

where $u_{a d s}[\mathrm{~kg} / \mathrm{kg}]$ and $u_{\text {des }}[\mathrm{kg} / \mathrm{kg}]$ represent the main adsorption and desorption functions, respectively, $R H[\%]$ the relative humidity. $u_{m}[\mathrm{~kg} / \mathrm{kg}]$ is the molecular moisture content, $u_{s a t}$ $[\mathrm{kg} / \mathrm{kg}]$ is the saturated moisture content, $a_{j}$ and $b_{j}$ depend on the molar heat of adsorption and the molar latent heat of vaporization. In practice, parameters are derived to fit experimental data.

The VG model was initially developed to predict the unsaturated hydraulic conductivity in soils and the equation of the model was then adapted for building materials by using relative humidity instead of capillary suction as state variable. It mathematically describes the main adsorption and desorption curves with a single relation given by Eq. (2) :

$$
u_{j}(R H)=u_{s a t}\left[\left(1+\left|\alpha_{j} \frac{R T}{M_{l} g} \ln (R H)\right|^{\eta_{j}}\right)^{-\left(1-\frac{1}{\eta_{j}}\right)}\right], j=\text { ads or des }
$$

$u_{\text {sat }}[\mathrm{kg} / \mathrm{kg}]$ is the saturated moisture content. $R\left[8.314 \mathrm{~J} \cdot \mathrm{mol}^{-1} \cdot \mathrm{K}^{-1}\right]$ is the ideal gas constant, $M_{l}$ [18 g.mol $\left.{ }^{-1}\right]$ the molar water mass, $g\left[9.81 \mathrm{~m}^{2} \cdot \mathrm{s}^{-1}\right]$ the gravity acceleration and $T[296.15 \mathrm{~K}]$ the reference temperature. Parameters $\alpha_{j}$ and $\eta_{j}$ are calculated by fitting experimental data.

\subsection{Hysteresis modelling}

Fig. 1 provides a schematic view of a hysteresis loop for a desorption / adsorption cycle. 


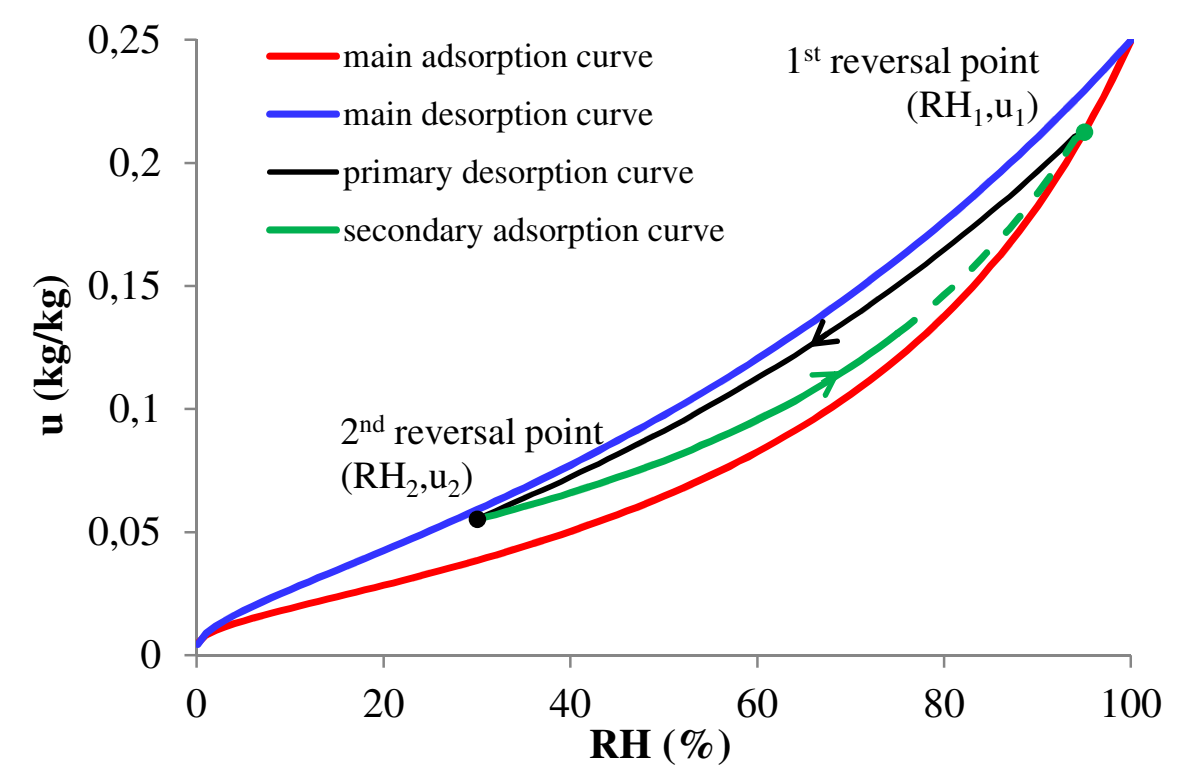

Fig. 1 Schematic view of main and intermediate scanning curves

According to Huang's model, equations (3) and (4) describe respectively the adsorption and desorption scanning curves after a series of alternating processes of desorption and adsorption:

$$
\begin{aligned}
& u(R H, i)=u_{r}(i)+\left(u_{s}(i)-u_{r}(i)\right) \frac{u_{a d s}(R H)}{u_{s a t}} \\
& u(R H, i)=u_{r}(i)+\left(u_{s}(i)-u_{r}(i)\right) \frac{u_{d e s}(R H)}{u_{s a t}}
\end{aligned}
$$

$i$ represents the number of switches between adsorption and desorption phases. $u_{r}(i)$ and $u_{s}(i)$ represent the residual and the saturated moisture contents, respectively. The calculation of these parameters is based on the perfect closure of the scanning curve at reversal points: scanning curve indexed $i$ includes the last reversal point $\left(R H_{i}, u_{i}\right)$ and the penultimate reversal point $\left(R H_{i-1}, u_{i-1}\right)$.

\subsection{Thermodynamic model}

The integration of the Clausius-Clapeyron relation [36] between two equilibrium states $\left(p_{v 1}\right.$, $\left.T_{1}\right)$ and $\left(p_{v 2}, T_{2}\right)$ gives the expression of isosteric heat $q_{s t}$ involved in a sorption process: 


$$
q_{s t}(u)=\frac{R}{M_{l}} \frac{T_{1} T_{2}}{T_{2}-T_{1}} \ln \left[\frac{p_{v}\left(T_{2}, u\right)}{p_{v}\left(T_{1}, u\right)}\right]
$$

$p_{v}=R H \cdot p_{s a t}(T)[\mathrm{Pa}]$ is the vapour pressure with $p_{\text {sat }}[\mathrm{Pa}]$ the saturated vapour pressure and $T$ $[\mathrm{K}]$ the temperature. The isosteric heat $q_{s t}$ is determined from the experimental data of sorption isotherms at two temperatures $\mathrm{T}_{1}$ and $\mathrm{T}_{2}$ and from equation (5).

In this paper, two approaches are presented. The first one proposed by Powers and Brownyard [46] consists in fitting the values of $q_{s t}(u)$ thanks to the PB equation:

$$
q_{s t}(u)=l_{v}+\frac{a}{(b-u)^{c}}
$$

$l_{v}\left[\mathrm{~J}_{\mathrm{kg}}^{-1}\right]$ is the latent heat of condensation and $a, b$ and $c$ are the fitting parameters.

The second approach consists in first fitting the two experimental isotherms with a sorption model and then express the function $q_{s t}(u)$ according to equation (5) [37]. This approach is thereafter named ThD model.

Whatever the chosen approach, the sorption isotherm at any temperature $\mathrm{T}$ is finally defined from a known sorption isotherm $R H\left(T_{r e f}, u\right)$ (with $T_{r e f}=T_{1}$ or $T_{2}$ ) and as follows:

$$
R H(T, u)=R H\left(T_{r e f}, u\right) \frac{p_{\text {sat }}\left(T_{r e f}\right)}{p_{\text {sat }}(T)} e^{q_{s t}(u) \frac{M_{l}\left(T-T_{r e f}\right)}{R \quad T_{r e f} T}}
$$

\section{Material and methods}

\subsection{Composition}

The material studied in this paper is a compacted precast hemp concrete manufactured by the French SME Easy Chanvre. The manufacturing process consists in mixing quicklime with water and in adding hydraulic lime and defibered hemp shiv. Fresh hemp concrete is filled into moulds and compacted by vibration to produce hemp concrete blocks. The size of the blocks is $30 \mathrm{~cm} \times 30 \mathrm{~cm} \times 16 \mathrm{~cm}$. Hemp concrete formulation is reported in Table 1 . Samples are cut in hemp concrete blocks stored for 2 years in a climatic room at $23^{\circ} \mathrm{C}$ and $50 \% \mathrm{RH}$ to 
ensure ageing. A total of 12 cubic samples representative of the material $\left(4.5 \times 4.5 \times 4.5 \mathrm{~cm}^{3}\right)$ are used.

Hemp shiv

Unslaked lime

Hydraulic lime

Water
$374 \mathrm{~kg}$

$415 \mathrm{~kg}$

$158 \mathrm{~kg}$

$207 \mathrm{~kg}$

Table 1 Hemp concrete formulation

\subsection{Density and porosity}

The dry bulk density $\rho_{0}$ is defined by:

$$
\rho_{0}=\frac{m_{s}}{V}
$$

In this relation, $m_{s}[\mathrm{~kg}]$ refers to the solid mass and $V\left[\mathrm{~m}^{3}\right]$ to the total volume. Each sample is oven dried, weighed and measured, giving the mass and the volume. The numerical value provided in the paper corresponds to an average of dry bulk densities calculated from the 12 samples.

The density of solid part $\rho_{r}$ is determined by Eq. (9) from the mass composition of the hemp concrete and the densities of solid part of its components:

$$
\rho_{r}=\frac{m_{s}}{V_{s}}=\frac{m_{b}+m_{h s}}{\frac{m_{b}}{\rho_{r, b}}+\frac{m_{h s}}{\rho_{r, h s}}}
$$

$V_{\mathrm{s}}\left[\mathrm{m}^{3}\right]$ is the volume of solid part of hemp concrete. Subscripts $b$ and $h s$ refer to the binder and hemp shiv, respectively.The densities of each solid part $\rho_{r, b}$ and $\rho_{r, h s}$ are experimentally determined by the pycnometer method in [5]: binder about $2400 \mathrm{~kg} \cdot \mathrm{m}^{-3}$ and hemp shiv about $1670 \mathrm{~kg} \cdot \mathrm{m}^{-3}$. 
The total porosity $n[\%]$ is the ratio of the pores volume to the total volume and is expressed by the relation:

$$
n=\frac{\rho_{r}-\rho_{0}}{\rho_{r}}
$$

The open porosity $n_{0}[\%]$ of porous materials is usually determined by hydrostatic weighting. This experimental method was impossible to implement for the studied hemp concrete: the immersion of the samples caused their decomposition. Chamoin used a hemp concrete with the same mix design but which differed in bulk density because of a higher compaction [5]. The hydrostatic weighting on this hemp concrete gave $n_{0}=68 \%$ with $\rho_{0}=450 \mathrm{~kg} \cdot \mathrm{m}^{-3}$. An alternative approach is proposed in this paper to determine the open porosity for the studied hemp concrete. Based on MEB views [9], this approach assumes that the closed pores are the micropores embedded in the binder. This implies that the closed pores / binder volume ratio is constant whatever the compaction of the hemp concrete:

$$
\left.\frac{V_{\text {closed pores }}}{V_{b}}\right|_{\text {Chamoin }}=\left.\frac{V_{\text {closed pores }}}{V_{b}}\right|_{\text {studied hemp concrete }}
$$

The open porosity is thus deduced from the relation:

$$
n_{0}=n-\frac{V_{\text {closed pores }}}{V}
$$

The saturated moisture content $u_{s a t}[\mathrm{~kg} / \mathrm{kg}]$ is given by the relation:

$$
u_{s a t}=n_{0} \frac{\rho_{w}}{\rho_{0}}
$$

$\rho_{w}\left[\mathrm{~kg} \cdot \mathrm{m}^{-3}\right]$ is the liquid water density.

The mass specific surface $S_{G A B}\left[\mathrm{~m}^{2} \cdot \mathrm{g}^{-1}\right]$ is determined from the relation:

$$
S_{G A B}=S_{w} N_{A} \frac{u_{m}}{M_{l}}
$$


$S_{w}\left[\approx 10 \dot{A^{2}}\right]$ represents the surface of one adsorbed water molecule, $N_{A}\left[6.02 \cdot 10^{23} \mathrm{~mol}^{-1}\right]$ the Avogadro's number. $u_{m}$ is determined from the GAB model by fitting the experimental data (Eq.1).

\subsection{Sorption isotherms}

The glass jar method is applied to determine sorption isotherms and sorption cycles in compliance with the EN ISO 12571 procedure. Two temperatures are investigated: $10^{\circ} \mathrm{C}$ and the reference temperature of $23^{\circ} \mathrm{C}$.

A balance with a resolution of $0.1 \mathrm{mg}$ is used to monitor the samples masses. Equilibrium is reached when the change in a sample mass is less than $0.1 \%$ within 24 hours. All samples are first dried under vacuum in silica gel to constant mass.

After conditioning, samples are placed into glass jars above a saturated salt solution. The following salts are used as shown in table 2.

\begin{tabular}{|c|c|c|c|c|}
\hline \multirow{2}{*}{ Temperature } & \multicolumn{4}{|c|}{ Equilibrium relative humidity } \\
\cline { 2 - 5 } & Potassium & Potassium & Magnesium & Potassium \\
& acetate & carbonate & nitrate & bromide \\
\hline $10^{\circ} \mathrm{C}$ & $23 \%$ & $43 \%$ & $57 \%$ & $85 \%$ \\
\hline $23^{\circ} \mathrm{C}$ & $23 \%$ & $43 \%$ & $53 \%$ & $81 \%$ \\
\hline
\end{tabular}

Table 2 Salts used in desiccators and their equilibrium relative humidity at $10^{\circ} \mathrm{C}$ and $23^{\circ} \mathrm{C}$

The temperature of $23^{\circ} \mathrm{C}$ is ensured by a climatic room. The measurements are performed at four relative humidity levels: $23 \%, 43 \%, 53 \%$ and $81 \%$. The samples are divided into two batches of 6 samples each. Six samples are taken stepwise from dry state to $23 \% \mathrm{RH}$ and 53\% RH to determine main adsorption curve data points. These samples are then taken stepwise from $53 \% \mathrm{RH}$ to $23 \% \mathrm{RH}$ and back to $53 \% \mathrm{RH}$ to determine intermediate scanning 
curve data points (primary desorption and secondary adsorption). The other six samples are taken stepwise from dry state to $81 \% \mathrm{RH}$ to determine main adsorption curve data point. These samples are then taken stepwise from $81 \% \mathrm{RH}$ to $43 \% \mathrm{RH}$ and $23 \% \mathrm{RH}$ and back to $43 \% \mathrm{RH}$ and $81 \%$ RH to determine intermediate scanning curve data points (primary desorption and secondary adsorption).

At $10^{\circ} \mathrm{C}$, dry samples masses were the same as those obtained before the test at $23^{\circ} \mathrm{C}$ (variations less than $0.03 \%$ ). The temperature of $10^{\circ} \mathrm{C}$ is obtained in a refrigerator. Because of its regulation system, temperature inside the refrigerator varies by a few degrees. To keep constant the temperature of the samples at $10^{\circ} \mathrm{C}$, desiccators are placed in an insulating box made with a $3 \mathrm{~cm}$ thick styrodur® polystyrene (Fig 2). Temperatures inside and outside the insulating box are monitored with thermocouples of type K. During the tests, temperature variations inside the box do not exceed $\pm 0.5^{\circ} \mathrm{C}$. The main adsorption data points were obtained increasing relative humidity from dry state to $23 \%, 43 \%, 57 \%$ and $85 \%$. Then the primary desorption curve was determined decreasing relative humidity from $85 \%$ to $23 \%$.

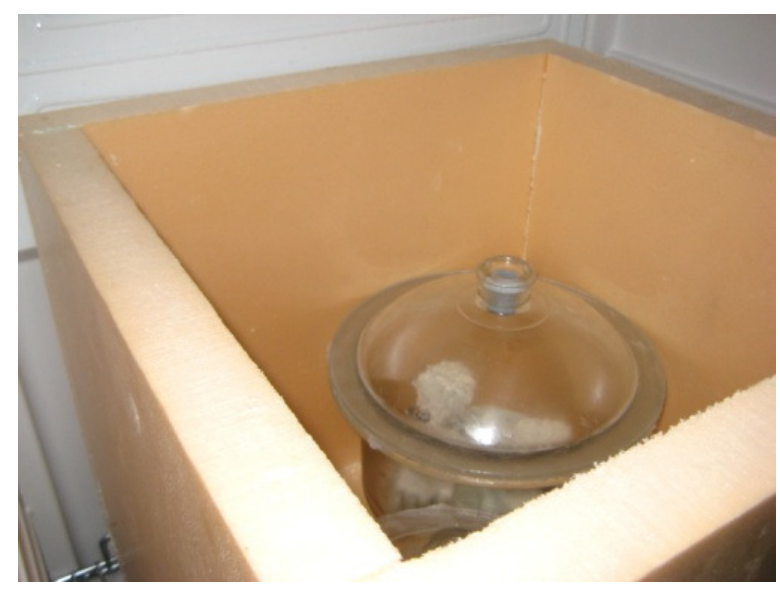

Fig. 2 Desiccators in the insulating box

\section{Results and discussion}

\subsection{Density and porosity}


Table 3 presents the physical characteristics of the studied hemp concrete. The physical properties obtained are consistent with the literature data $[3,5,7,9]$. Hemp concrete is a lightweight concrete in which open porosity accounts for a large part of the total porosity. The pore network consists of pores interconnected to the external surface.

Although the few experimental points at very low relative humidities provide a rough estimation of the specific area, the numerical value is consistent with the data found in literature, between 20 and $60 \mathrm{~m}^{2} \cdot \mathrm{g}^{-1}$ for hemp concrete $[3,5]$.

Density of solid part $\rho_{\mathrm{r}}$

Dry density $\rho_{0}$

Open porosity $n_{0}$

Total porosity $n$

Saturated moisture content $\mathrm{u}_{\mathrm{sat}}$

Specific surface area estimated from the $\mathrm{GAB}$ model at $23^{\circ} \mathrm{C}$
$2100 \mathrm{~kg} \cdot \mathrm{m}^{-3}$

$396 \mathrm{~kg} \cdot \mathrm{m}^{-3}$

$72 \%$

$81 \%$

$1.805 \mathrm{~kg} / \mathrm{kg}$

$59 \mathrm{~m}^{2} \cdot \mathrm{g}^{-1}$

Table 3 Physical properties of hemp concrete

\subsection{Results at the reference temperature of $23^{\circ} \mathrm{C}$}

The parameters of $\mathrm{VG}$ and $\mathrm{GAB}$ equations for the main adsorption curve are derived to fit the experimental data with the least squares method.

The saturated state is difficult or even impossible to achieve for porous bio-based materials (appearance of moulds at very high relative humidities, quick emptying of large pores at saturation). Usually, only experimental data of moisture content between $0 \%$ and $97 \%$ are known. An original approach, largely developed and validated in [13], is used in this paper. By using the Huang hysteresis model $(\mathrm{HH})$, the parameters of $\mathrm{VG}$ and $\mathrm{GAB}$ equations for the 
main desorption curve listed in table 4 are derived with the least squares method to fit the experimental data (here 81-43-23\%) as a primary desorption curve. Fig. 3 a) and b) provide experimental data, the fitted main adsorption and the primary desorption curve $81-43-23 \% \mathrm{RH}$ determined from VG and GAB equations, respectively. In these figures, the predicted main desorption curve, primary desorption curve $53-23 \% \mathrm{RH}$ and secondary adsorption curves 23 43-81\% RH and 23-53\%RH are also plotted.

\begin{tabular}{llll}
\hline Temperature & Model & Parameter & Value \\
\hline $23^{\circ} \mathrm{C}$ & VG & $\alpha_{\text {ads }}$ & 0.0319 \\
& $\eta_{\text {ads }}$ & 1.8096 \\
& $\alpha_{\text {des }}$ & 0.0151 \\
& $\eta_{\text {des }}$ & 1.4058 \\
& GAB & $a_{\text {ads }}$ & 25.985 \\
& & $b_{\text {ads }}$ & 0.9950 \\
& & $a_{\text {des }}$ & 26.159 \\
& & $b_{\text {des }}$ & 0.5982 \\
\hline $10^{\circ} \mathrm{C}$ & & $\alpha_{\text {ads }}$ & 0.006956 \\
& VG & $\eta_{\text {ads }}$ & 2.0008 \\
& GAB & $a_{\text {ads }}$ & 7.7810 \\
& $b_{\text {ads }}$ & 0.9916
\end{tabular}

Table 4 Parameters of $V G$ and GAB equations for hemp concrete 


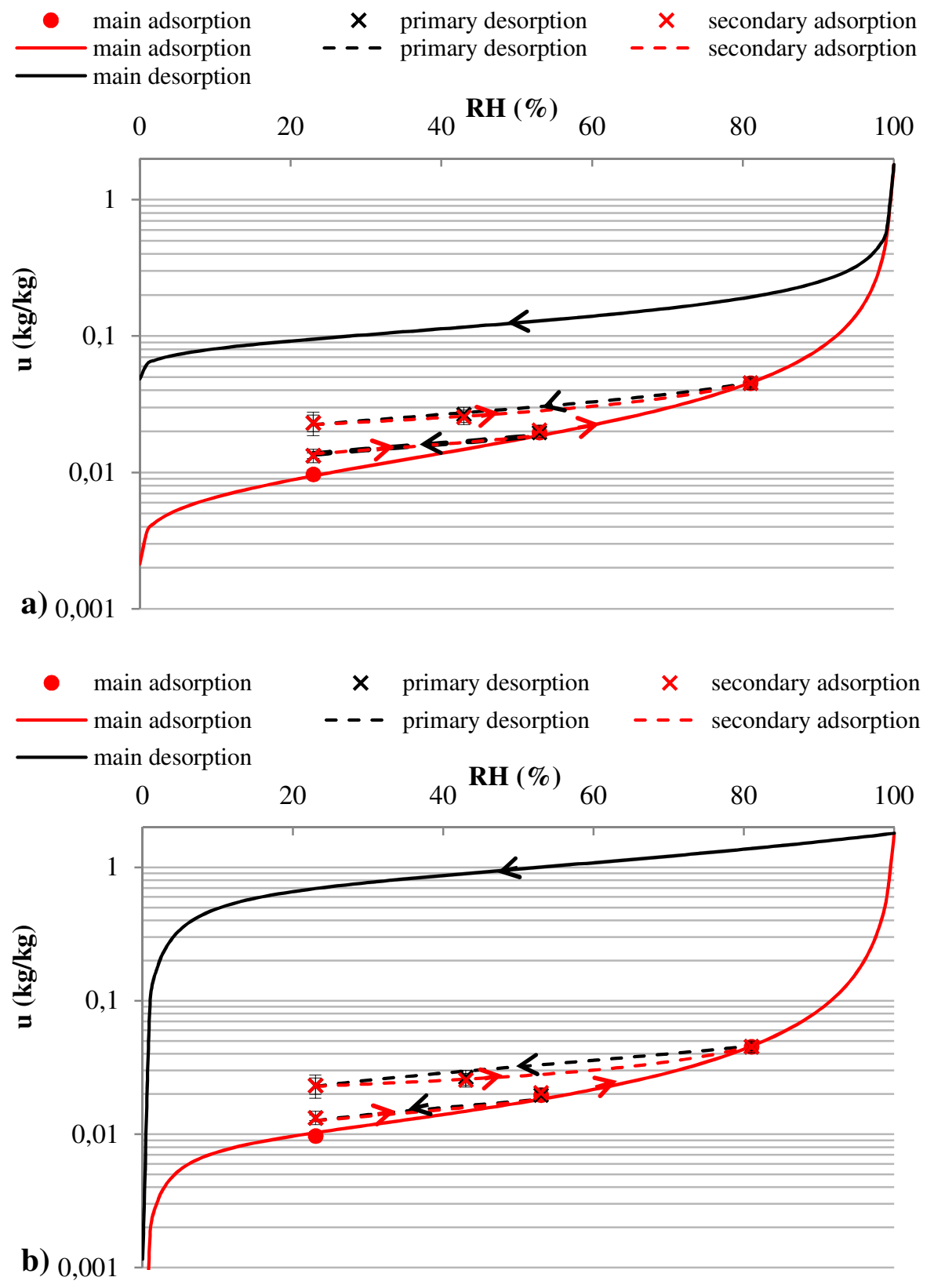

Fig. 3 Experimental (bullets) and numerical results (lines) at the reference temperature of $23^{\circ} \mathrm{C}$ with $V G$ equation a) and $G A B$ equation $b$ )

Associated with VG equation or with GAB equation, the $\mathrm{HH}$ model is in very good agreement with experimental data. It shows its relevance to predict scanning curves in hemp concrete at the reference temperature of $23^{\circ} \mathrm{C}$. It gives also hygric capacities (slopes of the curve) close to the experimental ones. The main desorption curve obtained from the GAB equation reaches higher moisture contents than from the VG equation on a large range of relative humidity. Differences are about one order of magnitude. 
Associated with the $\mathrm{HH}$ model, VG and GAB equations are suitable to predict any scanning curve for the studied relative humidity range.

\subsection{Influence of temperature on sorption isotherms}

\subsubsection{Sorption isotherm at $10^{\circ} \mathrm{C}$}

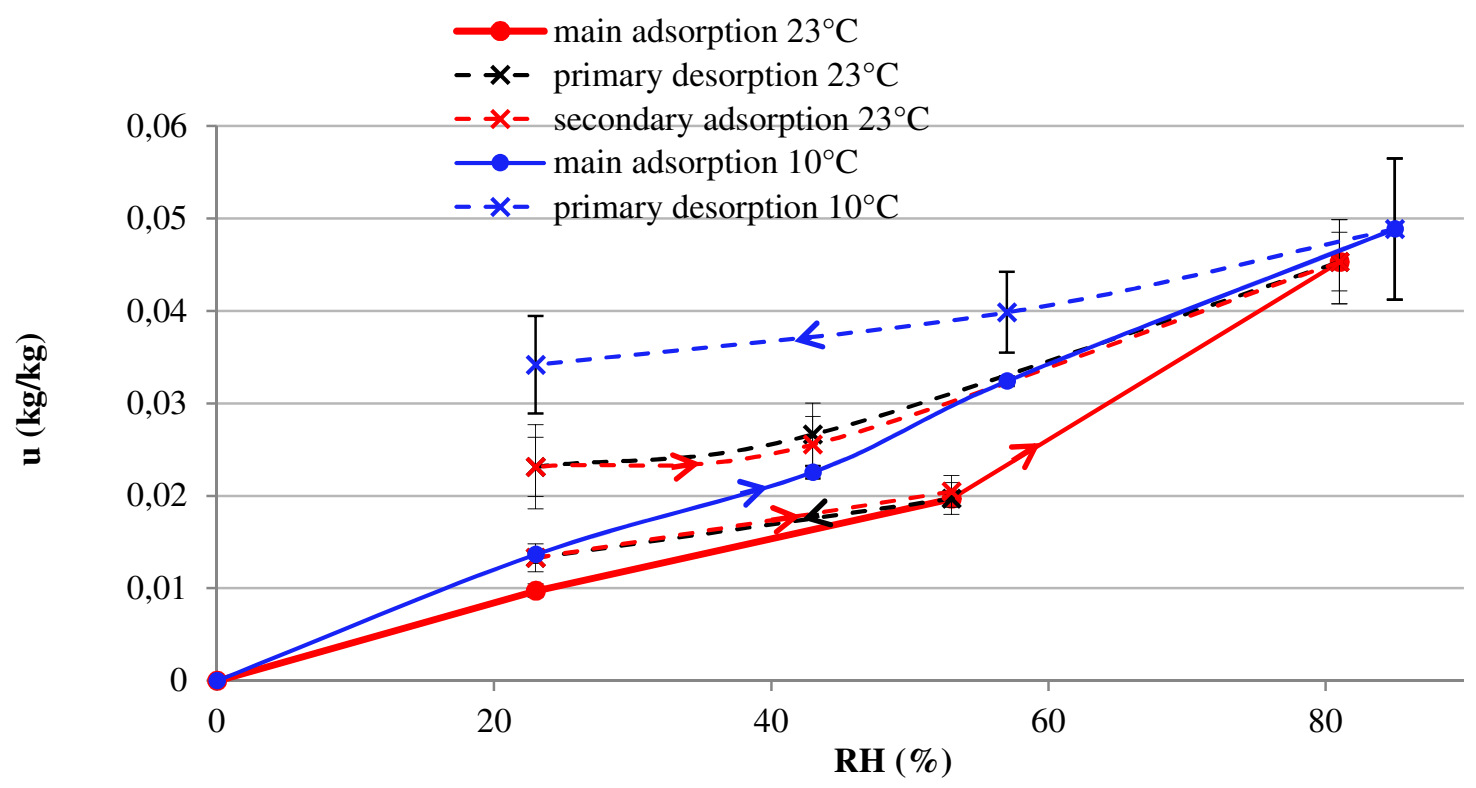

Fig. 4 Experimental primary desorption and secondary adsorption measurements (dashed lines and crosses) and experimental main adsorption measurements (solid lines and filled circles)

The experimental results at $10^{\circ} \mathrm{C}$ and at $23^{\circ} \mathrm{C}$ are compared in Fig.4. As expected, moisture content decreases when the temperature increases over the studied relative humidity range. The deviation between moisture content at $10^{\circ} \mathrm{C}$ and $23^{\circ} \mathrm{C}$ is slight at high relative humidity. Whatever the temperature, the hygric capacities for the intermediate scanning curves are lower than the hygric capacities for the main adsorption isotherms. The reduction of hygric capacities is significant at low temperature: the average hygric capacity of the primary desorption curve (calculated over the range $[23 \% \mathrm{RH}-81 \% \mathrm{RH}]$ ) is reduced by $38 \%$ at $23^{\circ} \mathrm{C}$ 
instead of $58 \%$ at $10^{\circ} \mathrm{C}$ (over the range $[23 \% \mathrm{RH}-85 \% \mathrm{RH}]$ ). These experimental results highlight the temperature influence on the hysteretic sorption process in hemp concrete.

\subsubsection{Isosteric heat of sorption}

Mass isosteric heat of sorption $q_{s t}$ is plotted on a dual scale $u$ and ratio $u / u_{m}$ in Fig. 5.

Unlike previous studies [21, 23, 37], no maximal value is highlighted at low moisture contents because the studied range of relative humidities does not cover the range [0\%-23\%]. For the studied hemp concrete, isosteric heat decreases and tends to the latent heat of condensation $l_{v}\left(2.45 \mathrm{MJ} \cdot \mathrm{kg}^{-1}\right)$ at a moisture content about 5\%, approximately (note that due to experimental uncertainty $q_{s t}$ at $u=4.88 \%$ is slightly below the value of $l_{v}$ ). This value of $5 \%$ is similar to those found in literature for cementitious materials or concrete $[21,23,37]$, for example Poyet found $q_{s t} \rightarrow l_{v}$ for $u \approx 4.5 \%$ [37].

This can be explained by similar specific surface areas for these materials: $59 \mathrm{~m}^{2} \cdot \mathrm{g}^{-1}$ at $23^{\circ} \mathrm{C}$ for the studied hemp concrete and $41 \mathrm{~m}^{2} \cdot \mathrm{g}^{-1}$ at $30^{\circ} \mathrm{C}$ for the concrete studied by Poyet (in accordance with the values found in literature for cementitious materials between 20 and 200 $\left.\mathrm{m}^{2} \cdot \mathrm{g}^{-1}[47-48]\right)$

The main difference between cementitious materials or concretes and hemp concrete comes from the degree of saturation $\left(=u / u_{s a t}\right)$ for which $q_{s t}$ tends to the latent heat of condensation. Whereas Poyet found a degree of saturation about 1 when $q_{s t}$ tends to $l_{v}$, this value for hemp concrete is about 0.027 . This difference is due to the open porosity, very different for both concrete: $72 \%$ for the studied hemp concrete and $10-15 \%$ for Poyet's concrete.

The three parameters of the PB equation (6) are derived to fit the experimental data: $\mathrm{a}=0.697$ $\mathrm{J} . \mathrm{kg}^{-1}, \mathrm{~b}=0.0886 \mathrm{~kg} / \mathrm{kg}$ and $\mathrm{c}=6.443$. For the ThD model, the fitting parameters of the VG equation and the GAB equation are provided in table 4.

Fig. 5 provides the evolution of the isosteric heat for the three numerical approaches: the PB equation, the ThD model associated with the VG equation and the ThD model associated with 
the GAB equation. Over the studied range, numerical results performed with the PB equation and the ThD model associated with the VG equation are very close. The ThD model with the GAB equation predicts values of $q_{s t}$ slightly higher than the previous models. Over the range [0\% RH-23\% RH], the deviations are noticeable, especially for ThD model associated with the GAB equation. Numerical results present a maximum value. In accordance with Drouet's assumption for cement-based pastes, the VG equation is unable to represent the maximal isosteric heat [23].

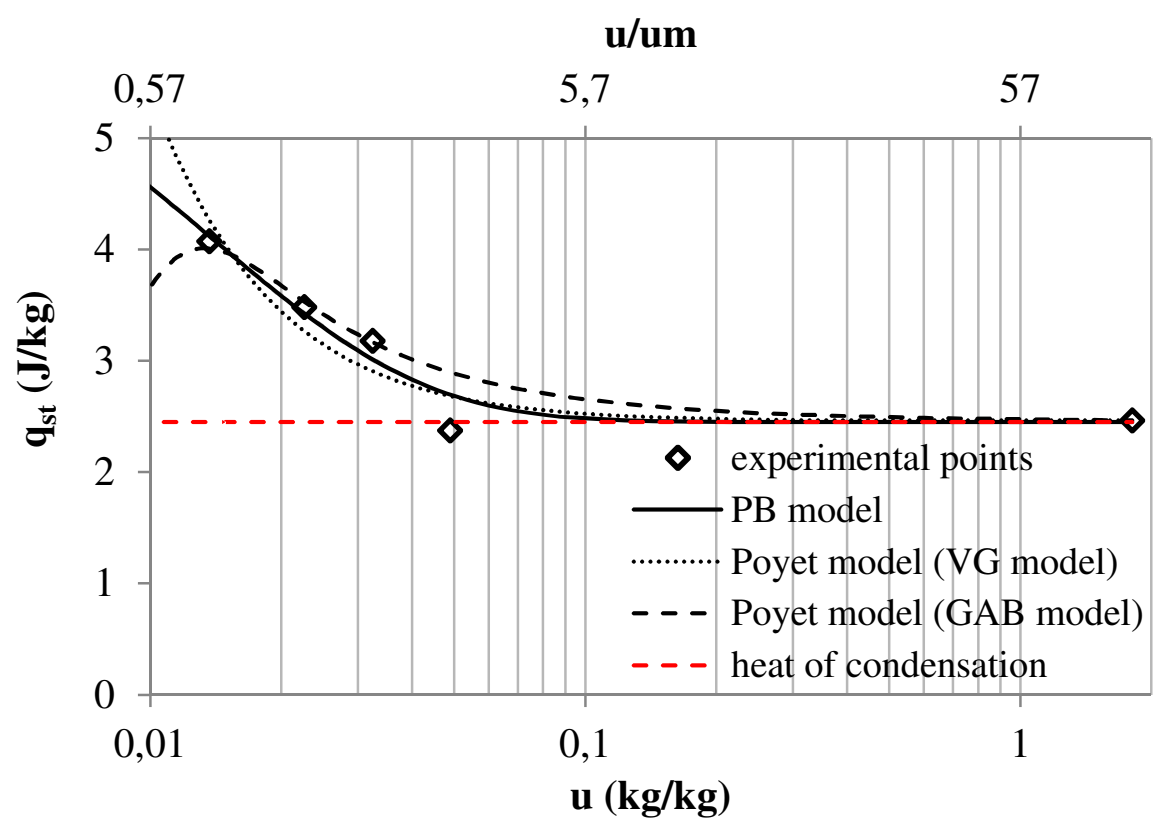

Fig. 5 Isosteric heat of sorption: experimental and numerical results

\subsubsection{Prediction of sorption isotherms}

By using equation (7) and $T_{r e f}=23^{\circ} \mathrm{C}$, the main adsorption and desorption isotherms are derived for temperatures from $5^{\circ} \mathrm{C}$ to $35^{\circ} \mathrm{C}$ and are presented in Fig. 6 a) to d). This range of temperatures is representative of the ambient temperature variations in France. In these figures, both $\mathrm{PB}$ equation and $\mathrm{ThD}$ model are compared using respectively $\mathrm{VG}$ and $\mathrm{GAB}$ equations. 
a) $\quad$\begin{tabular}{llllll} 
& \multicolumn{4}{c}{$\mathbf{R H}$} \\
& $20 \%$ & $40 \%$ & $60 \%$ & $80 \%$ & $100 \%$
\end{tabular}

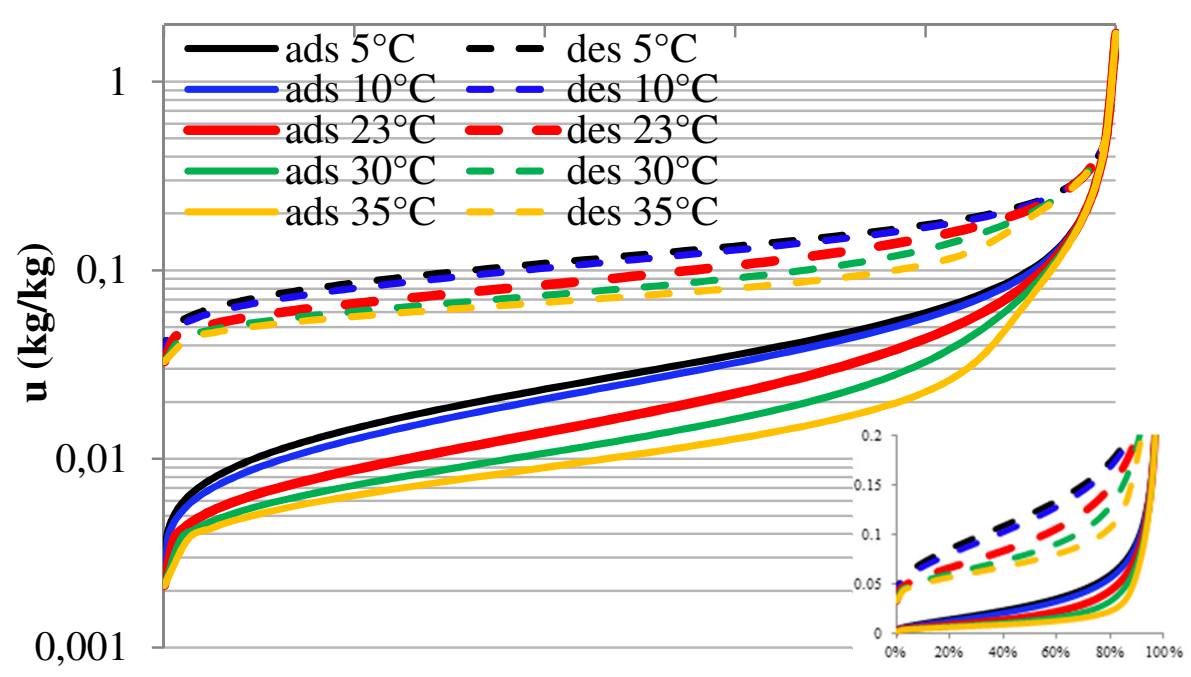

b)

RH

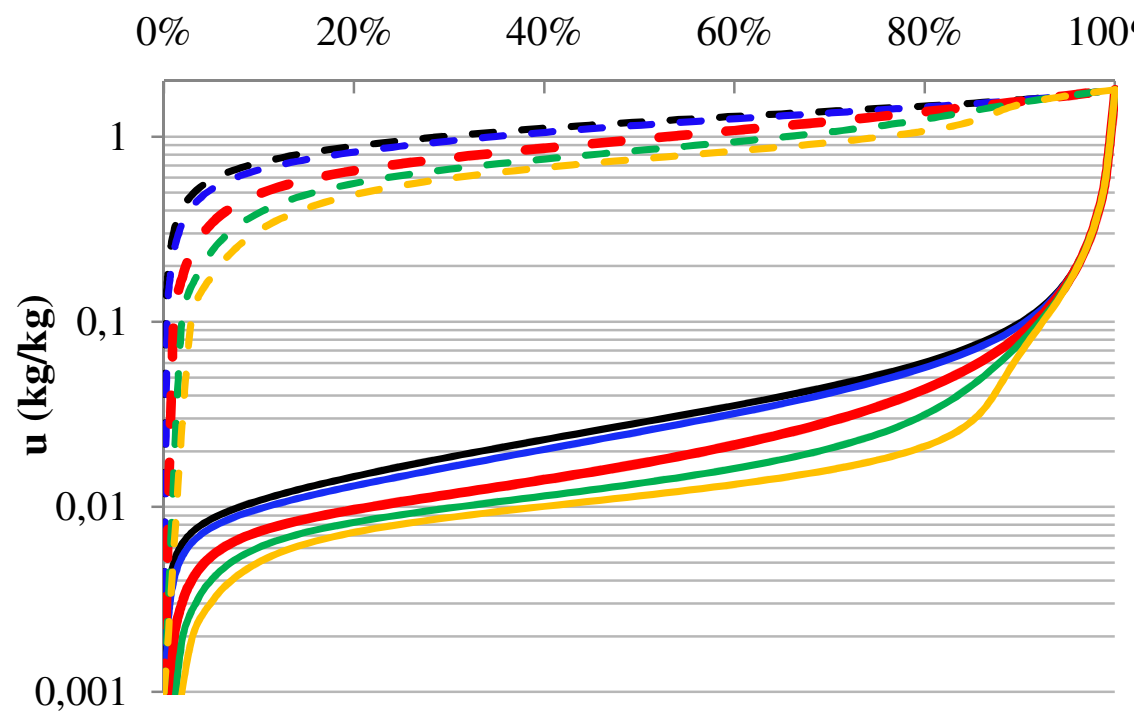



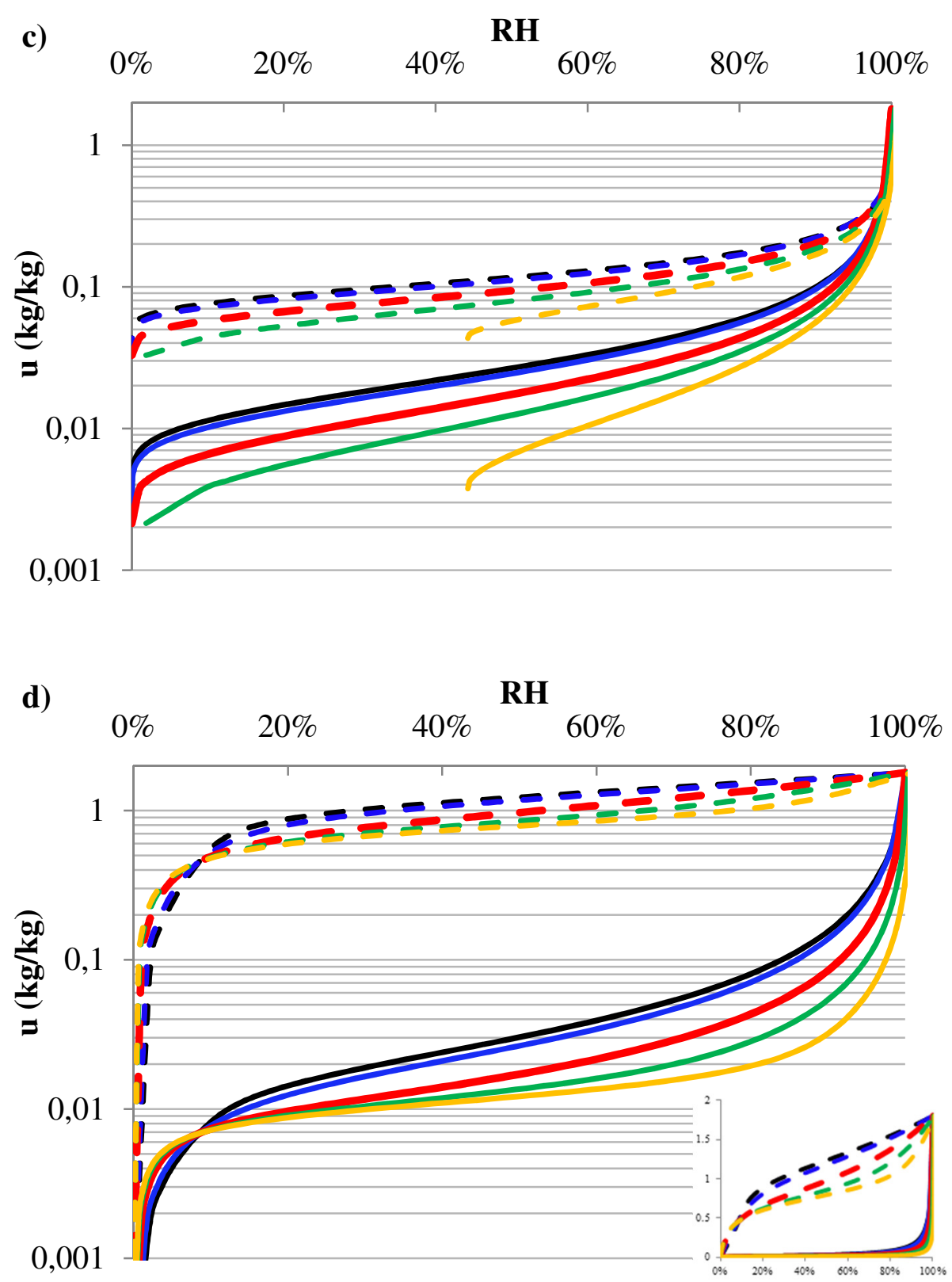

Figure 6 Main adsorption and desorption isotherms at different temperatures: a) PB equation associated with VG equation, b) PB equation associated with GAB equation, c) ThD model associated with VG equation and d) ThD model associated with GAB equation

For all the numerical simulations, it has to be noted that the hysteresis loop is reduced when temperature increases. As the logarithmic scale used for the moisture content does not highlight this effect of temperature, a no-logarithmic scale in the lower-right corner in Figs. 7 
a) and d) is provided. This is in accordance with the hypothesis of Ishida [39] on cementitious materials: the increase of temperature reduces the hysteresis loop.

In Fig. 6 a) and b), the PB equation for both $\mathrm{VG}$ and GAB equations causes a significant convergence of the different sorption isotherms at very high relative humidities. This can be explained by the shape of the isosteric heat which tends quickly towards the heat of condensation at high moisture contents. Fig. 6 c) shows the limits of the VG equation. For high temperatures (yellow curve), the VG equation associated with the ThD model is unable to predict moisture content at low relative humidities. Over this range of relative humidities, the isosteric heat obtained reaches very high values (see Fig. 5) which explains the irrelevance of the results. On the contrary, as the GAB equation associated with the ThD model gives an isosteric heat of sorption which presents a maximum value at low moisture content, relevant sorption isotherms are derived whatever the temperature.

\subsubsection{Hysteresis and temperature}

In this paragraph, the ability of the Huang hysteresis $(\mathrm{HH})$ model associated with the VG and $\mathrm{GAB}$ equations to predict the hemp concrete hysteretic behaviour is discussed. At $10^{\circ} \mathrm{C}$, the main adsorption curve was experimentally characterised and numerically modelled. The previous section 4.3.3. based on the work of Poyet made possible the determination of the main desorption curve at $10^{\circ} \mathrm{C}$. From the main adsorption and a primary desorption curves, the $\mathrm{HH}$ model is able to predict any intermediate scanning curve. In Fig. 7, experimental and numerical main adsorption curves and primary desorption curves $85-57-23 \% \mathrm{RH}$ at $10^{\circ} \mathrm{C}$ are compared. Associated with the HH model, the VG equation gives a primary desorption curve closer to the experimental one in comparison with the GAB equation. The discrepancies between numerical predictions and experimental results for the GAB equation can be explained by an inaccurate fitting of the main adsorption curves at $85 \% \mathrm{RH}$. 


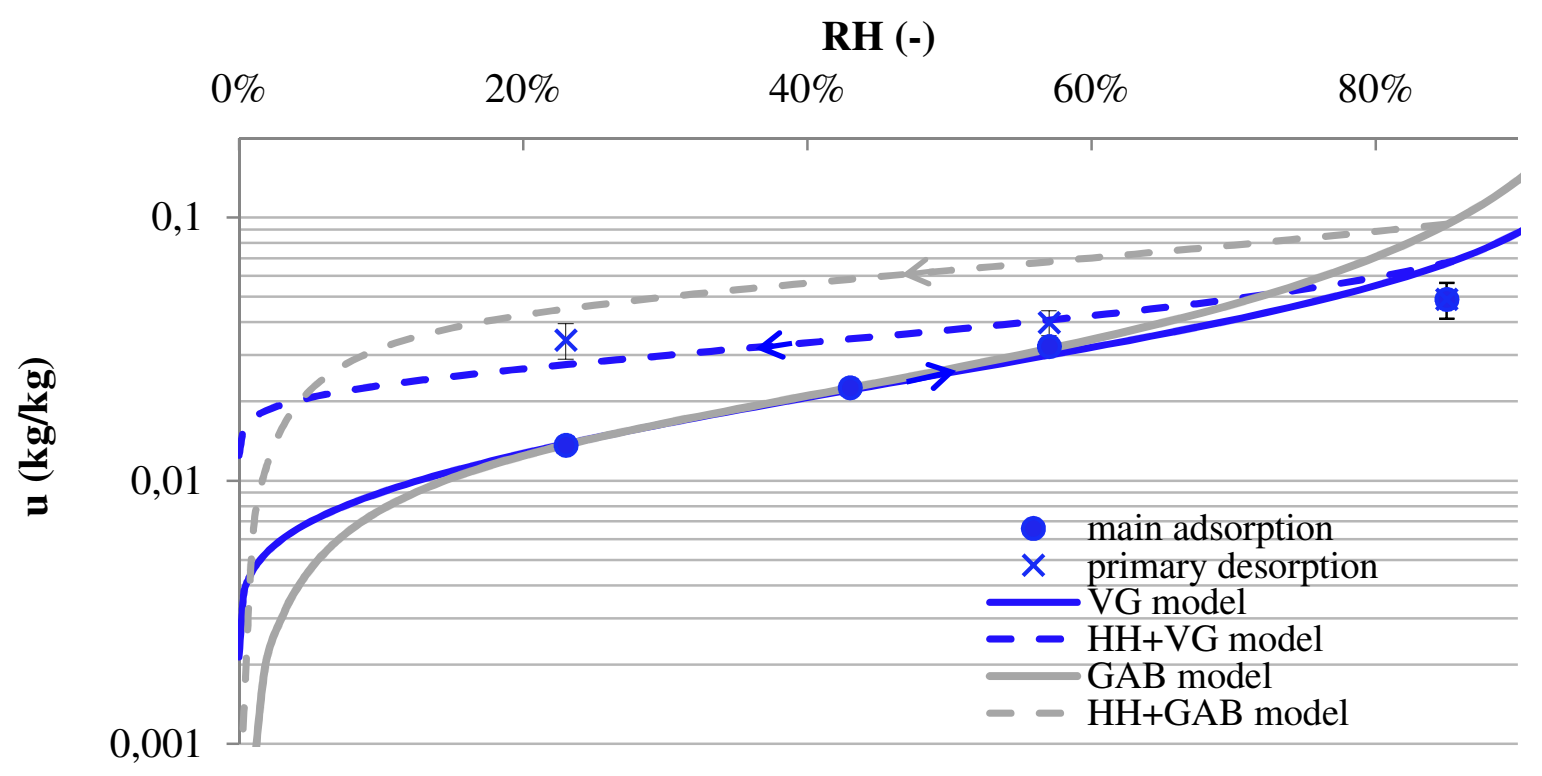

Figure 7 Experimental (bullets) and numerical main adsorption curves (solid lines) and primary desorption curves (dotted lines) at the temperature of $10^{\circ} \mathrm{C}$

A comparison between the average experimental and numerical hygric capacities is reported in table 5. It shows that some discrepancies remain but also that the results are relevant. As at $23^{\circ} \mathrm{C}$, hysteresis at $10^{\circ} \mathrm{C}$ decreases the hygric capacity. Both VG and GAB equations associated with the $\mathrm{HH}$ model are able to take into account this reduction of hygric capacity. The hygric capacities obtained with the VG equation are closer to the experimental ones than the hygric capacities obtained with the GAB equation. Nevertheless, the reduction of the hygric capacity between the main adsorption and the primary desorption is higher with the GAB equation (39\%) than with the VG equation (25\%).

\begin{tabular}{|c|c|c|c|c|c|c|}
\cline { 2 - 7 } \multicolumn{1}{c|}{} & \multicolumn{2}{c|}{ Experimental points } & \multicolumn{2}{c|}{ VG equation } & \multicolumn{2}{c|}{ GAB equation } \\
\cline { 2 - 7 } & Main & Primary & Main & Primary & Main & Primary \\
adsorption & desorption & adsorption & desorption & adsorption & desorption \\
\hline Hygric & 5.7 & 2.4 & 8.8 & 6.6 & 13.0 & 8.0 \\
\hline capacity (\%) & & & & \multicolumn{2}{c|}{$\mathbf{2 5 \%}$} & \multicolumn{2}{c|}{$\mathbf{3 9 \%}$} \\
\hline
\end{tabular}


Table 5 Average experimental and numerical hygric capacities at the temperature of $10^{\circ} \mathrm{C}$ between $23 \%$ RH and $85 \% R H$

This study shows that both VG and GAB equations, associated with the $\mathrm{HH}$ model, are able to give relevant results.

\section{Conclusion}

This paper provides some information concerning both the effects of temperature and hysteresis on sorption processes. These effects were assessed separately then jointly. As expected, experimental moisture content measured at $10^{\circ} \mathrm{C}$ and $23^{\circ} \mathrm{C}$ showed that a decrease of temperature results in an increase of moisture content at equilibrium. As at $10^{\circ} \mathrm{C}$ as at $23^{\circ} \mathrm{C}$, experimental scanning curves achieved on hemp concrete show that the hygric capacity is significantly reduced along a scanning curve and point out that hysteresis has a significant influence on the storage or release of moisture in hemp concrete.

The preliminary step to understand the influence of both temperature and hysteresis is to identify an accurate sorption isotherm model. In this paper, GAB and VG equations are investigated. Associated with the $\mathrm{HH}$ model, significant differences between VG and GAB equations are observed in the prediction of the main desorption curve but all predicted (desorption as well as adsorption) scanning curves are in good agreement with the experimental data.

The comparison of the numerical results for the prediction of sorption isotherms at different temperatures shows that $\mathrm{PB}$ equation can be used as a first approximation in a limited range of temperatures. It has the significant advantage to easily adapt to different sorption models. Nevertheless, it is not physically acceptable since it does not allow representing the physical evolution of the isosteric heat of sorption. On the contrary, the ThD model is able to do so. Associated with the GAB equation, the isosteric heat reaches a maximum value at low moisture content. However the ThD model remains dependent on the chosen sorption model. 
The VG equation fails to predict sorption isotherms at high temperatures for low relative humidities. Associated with the ThD model, the GAB equation seems to be the most relevant to predict sorption isotherms.

Finally the use of the $\mathrm{HH}$ model associated respectively with VG and GAB equations show some discrepancies between experimental and numerical primary desorption curve 85$23 \% \mathrm{RH}$ at $10^{\circ} \mathrm{C}$. These can be explained by a slight underestimation by the models of the experimental moisture content at $85 \% \mathrm{RH}$. However, the results remain relevant and show that the theoretical approach is promising.

The consistency of the calculation depends on the quality and quantity of the experimental results used for the estimation of the isosteric heat. In this way, complementary experimental results at very low and very high relative humidities should improve numerical results.

\section{Acknowledgements}

The authors acknowledge financial support of French Research Agency (ANR) and Region Bretagne for the experimental part of this work, within the frame of the projects BETONCHANVRE ANR-06-MAPR-0002 and PRIRECOMATX 2005.

The authors also thank the Easychanvre society for its contribution to the manufacturing of hemp concrete sampling.

\section{References}

[1] Pretot S, Collet F, Garnier C. Life cycle assessment of a hemp concrete wall: Impact of thickness and coating. Building and Environment 2014; 72: 223-31.

[2] Elfordy S, Lucas F, Tancret F, Scudeller Y, Goudet L. Mechanical and thermal properties of lime and hemp concrete ("hempcrete") manufactured by a projection process. Construction and Building Materials 2008; 22(10): 2116-23. 
[3] Collet F. Caractérisation hydrique et thermique de matériaux de génie civil à faibles impacts environnementaux [In French]. PhD thesis, Institut National des Sciences Appliquées de Rennes; 2004.

[4] Cerezo V. Propriété mécanique thermiques et acoustiques d'un matériau à base de particules végétales : approche expérimentale et modélisation théorique [In French]. PhD thesis, Ecole Nationale des Travaux Publics de l'Etat ; 2005.

[5] Chamoin J. Optimisation des propriétés (physiques, hydriques et mécaniques) de bétons de chanvre par la maîtrise de la formulation [In French]. PhD thesis, Université Européenne de Bretagne - Institut National des Sciences Appliquées de Rennes, 2013.

[6] De Brujin P, Johansson P. Moisture fixation and thermal properties of lime-hemp concrete. Construction and Building Materials 2013; 47: 1235-1242.

[7] Evrard A. Transient hygrothermal behaviour of Lime-Hemp Materials. PhD thesis, Katolieke Universiteit Leuven; 2008.

[8] Collet F, Pretot S. Experimental investigation of moisture buffering capacity of sprayed hemp concrete. Construction and Building Materials 2012; 36: 58-65.

[9] Collet F, Chamoin J, Pretot S, Lanos C. Comparison of the hygric behaviour of three hemp concretes. Energy and Buildings 2013; 62: 294-303.

[10] Moujalled B, Aït Oumeziane Y, Samri D, Stephan E, Moissette S, Bart M, Lanos C. Experimental and numerical evaluation of the hygrothermal performance of a hemp-lime building, 1st International Conference on Bio-based Building Materials, Clermont-Ferrand, France, $22^{\text {nd }}-24^{\text {th }}$ June 2015

[11] Shea A, Lawrence M, Walker P. Hygrothermal performance of an experimental hemplime building, Construction and Building Materials, 2012; 36: 270-275. 
[12] Samri D. Analyse physique et caractérisation hygrothermique des matériaux de construction: approche expérimentale et modélisation numérique [In French]. $\mathrm{PhD}$ thesis, Institut National des Sciences Appliquées de Lyon; 2008.

[13] Aït Oumeziane Y, Bart M, Moissette S, Lanos C. Hysteretic behaviour and moisture buffering of hemp concrete, Transport In Porous Media, 2014; 103: 515-533.

[14] Aït Oumeziane Y, Bart M, Moissette S, Lanos C, Collet F, Pretot S., Hysteresis phenomenon in hemp concrete, 1st International Conference on Bio-based Building Materials, Clermont-Ferrand, France, $22^{\text {nd }}-24^{\text {th }}$ June 2015.

[15] Aït Oumeziane Y. Evaluation des performances hygrothermiques d'une paroi par simulation numérique : application aux parois en béton de chanvre [In French]. $\mathrm{PhD}$ thesis, Université Européenne de Bretagne - Institut National des Sciences Appliquées de Rennes ; 2013.

[16] Huang H.C., Tan Y.C., Liu C.W., Chen C.H. A novel hysteresis model in unsaturated soil. Hydrological Procress, 2005; 19(8): 1653-65.

[17] Dwi Argo B. Détermination expérimentale de l'influence de l'hystérésis sur les propriétés hydriques des matériaux de Génie Civil [In French]. PhD thesis, - Institut National des Sciences Appliquées de Toulouse; 1994.

[18] Merouani L. Phénomène de sorption et de transfert d'humidité dans les bâtiments : étude expérimentale comparative d'un mortier de ciment et d'un enduit de façade [In French]. $\mathrm{PhD}$ thesis, Institut National Polytechnique de Grenoble, 1987.

[19] Hundt J, Kantelberg H. Sorptionsuntersuchungen an zemestein, zementmörtel und beton [In German], Deutscher Ausschuss für Stahlbeton Heft, 1978; 297: 25-39. 
[20] Daïan J.F. Condensation and isothermal water transfer in cement mortar Part I - Pore size distribution, equilibrium water condensation and imbibition, Transport in Porous Media, $1988 ; 3: 563-589$.

[21] Poyet S. Experimental investigation of the effect of temperature on the first desorption isotherm of concrete, Cement and Concrete Research, 2009; 39: 1052-59

[22] Brue F. Rôles de la température et de la composition sur le couplage thermohydromécanique des bétons [In French]. PhD thesis, Ecole Centrale de Lille, 2009 [23] Drouet E. Impact de la température sur la carbonatation des matériaux cimentaires - prise en compte des transferts hydriques [In French]. PhD thesis, Ecole Normale Supérieure de Cachan, 2010

[24] Navi P, Heger F. Comportement thermohydromécanique du bois : applications technologiques et dans les structures [In French], PPUR Suisse, 2005

[25] Merakeb S, Dubois F, Petit C. Modélisation des hystérésis de sorption dans les matériaux hygroscopiques [In French], Comptes Rendus de Mécanique, 2008 ; 337 : 34-39

[26] Yan Z, Sousa-Gallagher M.J., Oliveira F.A.R. Sorption isotherms and moisture sorption hysteresis of intermediate moisture content banana, Journal of Food Engineering, 2008; 86 (3): $342-348$.

[27] McLaughlin C.P., Magee T.R.A. The determination of sorption isotherm and the isosteric heats of sorption for potatoes, Journal of Food Engineering 1998; 35 (3): 267-280.

[28] McMinn W.A.M., Magee T.R.A. Thermodynamic properties of moisture sorption of potato, Journal of Food Engineering, 2003; 60 (2): 157-165. 
[29] Jamali A, Kouhila M, Ait Mohamed L, Jaouhari J.T., Idlimam A, Abdenouri N. Sorption isotherms of Chenopodium ambrosioides leaves at three temperatures, Journal of Food Engineering, 2006; 72 (1): 77-84.

[30] Radjy F, Richards C.W. Effect of curing and heat treatment history on the dynamic mechanical response and the pore structure of hardened cement paste, Cement and Concrete Research, 1973; 3 (1): 7-21.

[31] Bray W.H., Sellevold E.J. Water sorption properties of hardened cement paste cured or stored at elevated temperatures, Cement and Concrete Research, 1973; 3 (6): 723-728.

[32] Radjy F, Sellevold E.J., Hansen K.K. Isosteric vapor pressure-temperature data for water sorption in hardened cement paste: enthalpy, entropy and sorption isotherms at different temperatures, Report BYG-DTU R057, Technical University of Denmark (DTU), 2003.

[33] Bažant Z.P., Thonguthai W. Pore pressure and drying of concrete at high temperature, Journal of the Engineering Mechanics Division (ASCE), 1978; 104 (5): 1059-79.

[34] Bažant Z.P., Thonguthai W. Pore pressure in heated concrete walls - theoretical prediction, Magazine of Concrete Research, 1979; 31 (107): 67-76.

[35] Milly P.C.D. A linear analysis of thermal effects on evaporation from soil, Water Resources Research, 1984; 20: 1075-85.

[36] Brunauer S. The adsorption of gases and vapors - Volume I — Physical adsorption, Princeton University Press, 1945.

[37] Poyet S., Charles S. Temperature dependence of the sorption isotherms of cemented based materials: heat of sorption and Clausius-Clapeyron formula, Cement and Concrete Research, 2009; 39(11): 1060-67. 
[38] Rode C., Hansen K.K. Hysteresis and temperature dependency of moisture sorption new measurements, $9^{\text {th }}$ Nordic Symposium on Building Physics, 2011, Tampere, Finland.

[39] Ishida T, Maekawa K, Kishi T. Enhanced modeling of moisture equilibrium and transport in cementitious materials under arbitrary temperature and relative humidity history, Cement and Concrete Research, 2007; 37(4): 565-78.

[40] Brunauer S, Emmet P.H., Teller E, Adsorption of gases in multimolecular layers, Journal of the American Chemical Society, 1938; 60: 309-319.

[41] Guggenheim E.A. Application of Statistical Mechanics, Clarendon Press, Oxford, 1966, Chapter 11.

[42] Anderson R.B. Modifications of the Brunauer, Emmett and Teller, Journal of the American Chemical Society, 1946; 68 (4): 686-691.

[43] Anderson R.B., Hall W.K. Modifications of the Brunauer, Emmett and Teller, equation II, Journal of the American Chemical Society, 1948; 70 (5): 1727-1734.

[44] De Boer J.H. The Dynamical Character of Adsorption, Clarendon Press, Oxford, 1953. [45] Van Genuchten M. Th. A closed-form equation for predicting the hydraulic conductivity of unsaturated soils. Soil Science Society American Journal, 1980; 44: 892-98.

[46] Powers T.C., Brownyard T.L., Studies of the physical properties of the hardened cement paste, Portland Cement Association Bulletin n²2, 1948.

[47] Korpa A, Trettin R. The influence of different drying methods on cement paste microstructures as reflected by gas adsorption: comparison between freeze-drying, D-drying, P-drying and oven-drying, Cement and Concrete Research, 2006; 36 (4): 634-649. 
[48] Odler I. The BET-specific surface area of hydrated Portland cement and related materials, Cement and Concrete Research, 2003; 33 (12): 2049-2056. 